\title{
Nursing Apps for Education and Practice
}

\section{Tudor Calinici*}

Department of Medical Informatics and Biostatistics, University of Medicine and Pharmacy Cluj-Napoca, Cluj-Napoca, Romania

\begin{abstract}
The smartphone, bringing together the communication and information technologies, is a device that offers an easily and friendly access to the information. Mobile health applications (apps) are increasing popular and could become an integral part of our daily lives, no matter if we are students or health care professionals. Having the support and agreement of the leadership of the hospitals and health institutions, the nurse community is starting to use this technology in many different areas. The goal of this paper is to present the advantages and benefits of using the mobile health apps (mHealth apps) in nursing, to identify some mHealth apps for different specific nursing activities, to identify which competencies are needed to use those apps and to provide a way to evaluate the nursing apps.
\end{abstract}

Keywords: Smartphone; MHealth apps; Nursing

\section{Introduction}

The smartphone, bringing together the communication and information technologies, is a device that offers an easily and friendly access to the information. Mobile health applications (apps) are increasing popular and could become an integral part of our daily lives, transforming many aspects of clinical practice. The healthcare professionals are using those apps in very different areas such as accessing health care records, medical education and training, time management, etc. $[1,2]$. There is no surprise that the use of mobile technology become popular in nursing community. The Wolters Kluwer Health survey, showed that $65 \%$ of nurses are [3] using mobile devices for professional purposes at work at least $30 \mathrm{~min}$ per day, while $20 \%$ use them for $2 \mathrm{~h}$ or more. $60 \%$ of respondents said that they use social media to follow healthcare issues at work and $86 \%$ said that they follow healthcare issues on social media outside of work. Roughly one-half of the respondents responded that their organization blocks access on company networks to social sites such as Facebook, Twitter, Pinterest and YouTube. Within the 95\% who responded that they access health information at work, $48 \%$ of them said that their healthcare institutions encourage nurses to access online resources; $41 \%$ allow for occasional use; and $5 \%$ only as a last resort. Those data suggests that the use of mHealth apps is becoming one of the common activities of the nurses.

The mobile applications, or mobile apps, could be software applications running on a mobile device (i.e., a handheld commercial off-the-shelf computing platform, with or without wireless connectivity) or a web-based software application tailored to a mobile platform but executed on a server [4]. A smartphone is a mobile phone (also known as cell phones or cell mobiles) with an advanced mobile operating system that combines features of a personal computer operating system with other features useful for mobile or handheld use. Smartphones, which are usually pocket-sized, typically [5] combine the features of a mobile phone, such as the abilities to place and receive voice calls and create and receive text messages, with those of other popular digital mobile devices like Personal Digital Assistants (PDAs), such as an event calendar, media player, video games, GPS navigation, digital camera and digital video camera. Smartphones can access the Internet and can run a variety of third-party software components ("apps" from Google Play, Apple [6,7] App Store, etc.).

In the article "The Impact of Technology in Nursing", Morales said that "The most [8] common technology in the workplace includes cell phones" and "'nurses are embracing social media; 11\% use Twitter;
77\% have visited Facebook". She suggests that one of the helpful ways to use of the power of mobile technology in nursing is to access the guidelines available on the internet [9-11].

Seabrook et al. [12] "undertook an environmental scan and classification of the medical app landscape in the two dominant platforms by searching the medical category of the Apple iTunes and Google Play app download sites". They found that the proportion of Apple iOS apps for the public (35\%) and for physicians (36\%) is similar and Few Apple iOS apps specifically target nurses (3\%). So, even if the number of nurse dedicated apps is smaller than the number for clinicians or physicians, it will be a challenge for the nurses to identify the best available nursing apps.

\section{Technology and Nursing Practice}

American Association of Colleges of Nursing suggests that the nurses should "demonstrate skills in using patient care technologies, information systems, and communication devices that support safe nursing practice" [13]. The institutions involved in nursing education must do in such way "to promote quality education that prepares a workforce capable of practicing in a healthcare environment where technology continuous to increase in amount and sophistication" [14].

So, in nursing practice, the computer literacy has become a survival skill for the profession. The nurses must have [15] technology skills of the entry-level; they must know how to use the nursing-specific software such as computerized documentation [16].

\section{Mobile Technology in Nursing Education}

We are witnesses of a change in learning paradigm. The 'digital natives' students think and communicate differently from previous generations. They use the mobile technology and they expect that the mobile technology to be used in their education, together with

*Corresponding author: Tudor Calinici, Department of Medical Informatics and Biostatistics, Faculty of Medicine, University of Medicine and Pharmacy ClujNapoca, 400495, Pasteur St. No. 6, Cluj-Napoca, Romania, Tel: 0374834502; E-mail: tcalinici@umfcluj.ro

Received May 25, 2017; Accepted June 09, 2017; Published June 13, 2017

Citation: Calinici T (2017) Nursing Apps for Education and Practice. J Health Med Informat 8: 262. doi: 10.4172/2157-7420.1000262

Copyright: @ 2017 Calinici T. This is an open-access article distributed under the terms of the Creative Commons Attribution License, which permits unrestricted use, distribution, and reproduction in any medium, provided the original author and source are credited. 
other innovative computer based technologies [17-20] both in formal or informal learning environments. As evident advantages, mobile technology allows teachers and students to:

- Access and create multimedia materials.

- Produce digital narratives.

- Explore emerging literacies.

There are studies which indicate that the usage of mobile technology helps the educators to improve the motivation and the learning outcomes and the nurses to improve their skills and the confidence in performance $[21,22]$.

\section{Nursing Apps on Different Domains}

There are many domains in which the mobile apps can be used in nursing education and practice. The following tables contain a number of applications which nurses and the persons involved in nursing education can use for specific purposes. There are many other apps; this list is made according to the author's experience and preference. All the apps that are in the following list were tested by the author.

Table 1 contains a list of apps which can be used to assist in promoting learning or engaging the learners in learning process. You can find the name of the application and the hyperlink to the app for Android and Apple devices (if available).

Table 2 contains mobile apps that can be used in order to assist learning.

Table 3 contains a list of apps which can be used to find just-in-time resources.

The critical evaluation of nursing mobile apps:

\begin{tabular}{|l|l|l|}
\hline App Name & Scope & Description and download link(s) \\
\hline Prezi & Presentation tools & $\begin{array}{l}\text { https://play.google.com/store/apps/details?id=com.prezi.android\&hl=en } \\
\text { https://itunes.apple.com/us/app/prezi-viewer/id576717926?mt=8 }\end{array}$ \\
\hline Animoto & Presentation tools & $\begin{array}{l}\text { https://play.google.com/store/apps/details?id=com.animoto.android.videoslideshow\&hl=en } \\
\text { https://itunes.apple.com/us/app/animoto-video-slideshow-maker/id459248037?mt=8 }\end{array}$ \\
\hline NearPod & Presentation tools & $\begin{array}{l}\text { https://play.google.com/store/apps/details?id=com.panareadigital.Nearpod\&hl=en } \\
\text { https://itunes.apple.com/us/app/nearpod/id523540409?mt=8 }\end{array}$ \\
\hline ShowMe & Interactive whiteboard & https://itunes.apple.com/ro/app/showme-interactive-whiteboard/id445066279?mt=8 \\
\hline 3DBrain & Interactive whiteboard & $\begin{array}{l}\text { https://play.google.com/store/apps/details?id=org.dnalc.threedbrain\&hl=en } \\
\text { https://itunes.apple.com//ro/app/3d-brain/id331399332?mt=8 }\end{array}$ \\
\hline drawMD Orthopedic & Interactive whiteboard & https://itunes.apple.com/us/app/drawmd-orthopedics/id436181695?mt=8 \\
\hline Quizlet & $\begin{array}{l}\text { developing quizzes, crosswords, and } \\
\text { flash cards }\end{array}$ & $\begin{array}{l}\text { https://play.google.com/store/apps/details?id=com.quizlet.quizletandroid\&hl=en } \\
\text { https://itunes.apple.com/us/app/quizlet-study-flashcards-languages-vocabulary/id546473125?mt=8 }\end{array}$ \\
\hline Pool Everywhere & polling and assessment & $\begin{array}{l}\text { https://play.google.com/store/apps/details?id=com.polleverywhere.mobile\&hl=en } \\
\text { https://itunes.apple.com/ro/app/poll-everywhere/id893375312?mt=8 }\end{array}$ \\
\hline Socrative student & polling and assessment & $\begin{array}{l}\text { https://play.google.com/store/apps/details?id=com.socrative.student\&hl=en } \\
\text { https://itunes.apple.com/us/app/socrative-student/id477618130?mt=8 }\end{array}$ \\
\hline
\end{tabular}

Table 1: Apps for promoting learning or engaging the learners in learning process.

\begin{tabular}{|l|l|l|}
\hline App Name & Scope & Description and download link(s) \\
\hline Notability & note-taking & https://itunes.apple.com/us/app/notability/id360593530?mt=8 \\
\hline ColorNotes & note-taking & https://play.google.com/store/apps/details?id=com.socialnmobile.dictapps.notepad.color.note\&hl=en \\
\hline Kindle & e-reader & $\begin{array}{l}\text { https://play.google.com/store/apps/details?id=com.amazon.kindle\&hl=en } \\
\text { https://itunes.apple.com/us/app/kindle-read-ebooks-magazines-textbooks/id302584613?mt=8 }\end{array}$ \\
\hline Google docs & collaborative and file sharing & $\begin{array}{l}\text { https://play.google.com/store/apps/details?id=com.google.android.apps.docs.editors.docs\&hl=en } \\
\text { https://itunes.apple.com/us/app/google-docs/id842842640?mt=8 }\end{array}$ \\
\hline Dropbox & collaborative and file sharing & https://play.google.com/store/apps/details?id=com.dropbox.android\&hl=en \\
https://itunes.apple.com/ro/app/dropbox/id327630330?mt=8
\end{tabular}

Table 2: Apps to assist learning.

\begin{tabular}{|l|l|l|}
\hline App Name & Scope & Description and download link(s) \\
\hline BMI Calculator & quick references & $\begin{array}{l}\text { https://play.google.com/store/apps/details?id=com.splendapps.bmicalc\&hl=en } \\
\text { https://itunes.apple.com/ro/app/bmi-calculator/id550932668?mt=8 }\end{array}$ \\
\hline NIH Stroke Scale & quick references & $\begin{array}{l}\text { https://play.google.com/store/apps/details?id=com.myprograms.nihss\&hl=en } \\
\text { https://itunes.apple.com/us/app/nih-stroke-scale-from-statcoder/id408788598?mt=8 }\end{array}$ \\
\hline Pocket Lab Values & quick references & $\begin{array}{l}\text { https://play.google.com/store/apps/details?id=com.medplusapps.pocketlabvalues\&hl=en } \\
\text { https://itunes.apple.com/us/app/pocket-lab-values/id325010997?mt=8 }\end{array}$ \\
\hline Pedi STAT & quick references & $\begin{array}{l}\text { https://play.google.com/store/apps/details?id=com.qxmd.pedistat\&hl=en } \\
\text { https://itunes.apple.com/us/app/pedi-stat/id327963391?mt=8 }\end{array}$ \\
\hline Dementi Assist & disease/ situation specific & https://itunes.apple.com/us/app/dementiassist/id926516122?mt=8 \\
\hline StagingPU & disease/ situation specific & https://itunes.apple.com/us/app/stagingpu/id876903883?mt=8 \\
\hline
\end{tabular}

Table 3: Performance support apps. 
The main problem of medical apps is lack of evidence-based health information, as it was presented in the study of Abroms et al. [23]; regarding the way mobile phones are being used in novel ways to promote smoking cessation. In order to help nursing students to assess the credibility of mobile health care apps, Paula McNiel \& Erin C. McArthur developed the CRAAP evaluation criteria scale [24]. Using those criteria, the nurses are able to compute and interpret a score as it follows:

- $\quad$ Score between 45-50-Excellent Apps.

- $\quad$ Score between 40-44-Good Apps.

- $\quad$ Score between 35-39-Average Apps.

- Score between 30-34-Borderline acceptable Apps

- Score less than 30-Unacceptable Apps.

\section{Apps Advisory}

There are several institutions who tried to synthetize and to make a top of nursing apps. One example is Capella University [25-27], Rasmussen College or AMN Healthcare. But, because new apps are appearing every day, any advisory app list will, probably, not be upto-date.

\section{References}

1. Talwar YK, Karthikeyan S, Bindra N, Medhi B (2016) Smartphone-A userfriendly device to deliver affordable healthcare-A practical paradigm. $\mathrm{J}$ Health Med Informat 7: 232.

2. Ventola CL (2014) Mobile devices and apps for health care professionals: uses and benefits. Pharm Ther 39: 356-364.

3. http://wolterskluwer.com/company/newsroom/news/health/2014/09/wolterskluwer-health-survey-finds-nurses-and-healthcare-institutions-acceptingprofessional-use-of-online-reference--mobile-technology.html

4. http://www.fda.gov/downloads/MedicalDevices/.../UCM263366.pdf

5. Ishii K (2004) Internet use via mobile phone in Japan. Telecommun Policy 28: 43-58

6. https://play.google.com/

7. https://www.apple.com/itunes/
8. http://www.nursetogether.com/impact-technology-nursing

9. https://www.guidelinesfornurses.co.uk

10. http://www.ens4care.eu/heading-posts/ens4care-evidence-based-guidelinesfor-nurses-and-social-care-workers-for-the-deployment-of-ehealth-services-2/

11. https://www.nmbi.ie/Standards-Guidance/More-Standards-Guidance

12. Seabrook HJ, Stromer JN, Shevkenek C, Bharwani A, de Grood J, et al. (2014) Medical applications: a database and characterization of apps in Apple iOS and Android platforms. BMC Res Notes 7: 573.

13. http://www.aacn.nche.edu/education-resources/BaccEssentials08.pdf

14. Weaver C, Delaney C, Weber P, Carr R (2006) Nursing and Informatics for the 21st century: an international look at practice, education and EHR trends.

15. Excerpta Medica (1986) Public health, social medicine and hygiene. Nurs Clin North Am 20: 549-556.

16. American Library Association (2014) Information literacy competency standards for nursing: Approved by the ACRL Board of Directors. ACRL 75: 34-41.

17. Medley CF, Claydell Home, RN (2005) Using simulation technology for undergraduate nursing education. J Nurs Educ 44: 31.

18. Calinici T (2015) Virtual patients in emergency nursing training. J Nurs Care 4: 2167-1168.

19. Calinici T, Nistor F, Istrate D, Drugan T (2017) IT instruments for problem based learning in undergraduate medical education. MedEdPublish 6: 2.

20. Looi CK, Seow P, Zhang BH, So HJ, Chen W, et al. (2010) Leveraging mobile technology for sustainable seamlesslearning: a research agenda, Brit $\mathrm{J}$ Educ Tec 41: 154-169.

21. Lee SG, Shin YH (2016) Effects of self-directed feedback practice using smartphone videos on basic nursing skills, confidence in performance and learning satisfaction. J Korean Acad Nurs 46: 283-292.

22. Kim SJ, Shin H, Lee J, Kang S, Bartlett R (2017) A smartphone application to educate undergraduate nursing students about providing care for infant airway obstruction. Nurse Educ Tod 48: 145-152.

23. Abroms LC, Padmanabhan N, Thaweethai L, Phillips T (2011) iPhone apps for smoking cessation: a content analysis. Am J Prev Med 40: 279-285.

24. McNiel P, McArthur E (2016) Evaluating health mobile apps: information literacy in undergraduate and graduate nursing courses. J Nurs Educ 55: 480.

25. https://www.capella.edu/blogs/cublog/10-apps-for-nurses-in-online-nursingprograms/

26. http://www.rasmussen.edu/degrees/nursing/blog/best-nursing-apps/

27. https://www.americanmobile.com/nursezone/ 